\title{
Voltage-gated ion channels and gating modifier toxins
}

\author{
William A. Catterall ${ }^{1}{ }^{*}$, Sandrine Cestèle ${ }^{12}$, Vladimir Yarov-Yarovoy ${ }^{1}$, Frank H. Yu ${ }^{1}$, Keiichi Konoki ${ }^{1}$, Todd Scheuer ${ }^{1}$ \\ 1 Department of Pharmacology University of Washington, Seattle, WA 98195-7280,US \\ 2 Canaux calciques, fonctions et pathologies INSERM : U607, CEA : DSV/IRTSV, Université Joseph Fourier - Grenoble I, 17, rue des \\ martyrs 38054 Grenoble, FR \\ * Correspondence should be adressed to: William Catterall <wcatt@u.washington.edu >
}

\begin{abstract}
Voltage-gated sodium, calcium, and potassium channels generate electrical signals required for action potential generation and conduction and are the molecular targets for a broad range of potent neurotoxins. These channels are built on a common structural motif containing six transmembrane segments and a pore loop. Their pores are formed by the S5/S6 segments and the pore loop between them and are gated by bending of the $\mathrm{S6}$ segments at a hinge glycine or proline residue. The voltage sensor domain consists of the S1 to S4 segments, with positively charged residues in the S4 segment serving as gating charges. The diversity of toxin action on these channels is illustrated by sodium channels, which are the molecular targets for toxins that act at five or more distinct receptor sites on the channel protein. Both hydrophilic low molecular weight toxins and larger polypeptide toxins physically block the pore and prevent sodium conductance. Hydrophobic alkaloid toxins and related lipid-soluble toxins act at intramembrane sites and alter voltage-dependent gating of sodium channels via an allosteric mechanism. In contrast, polypeptide toxins alter channel gating by voltage-sensor trapping through binding to extracellular receptor sites, and this toxin interaction has now been modeled at the atomic level for a $\beta$-scorpion toxin. The voltage sensor trapping mechanism may be a common mode of action for polypeptide gating modifier toxins acting on all of the voltage gated ion channels.
\end{abstract}

MESH Keywords Animals ; Humans ; Ion Channel Gating ; drug effects ; physiology ; Ion Channels ; drug effects ; Neurotoxins ; pharmacology ; Venoms ; pharmacology Author Keywords Sodium channel ; neurotoxins ; tetrodotoxin ; saxitoxin ; scorpion toxins ; anemone toxins ; batrachotoxin ; veratridine ; conotoxins ; toxin receptor sites ; insect toxins

\section{The Voltage-Gated Ion Channels}

Electrical signals control contraction of muscle, secretion of hormones, sensation of the environment, processing of information in the brain, and output from the brain to peripheral tissues. In excitable cells, electrical signals also have an important influence on intracellular metabolism and signal transduction, gene expression, protein synthesis and targeting, and protein degradation. In all of these contexts, electrical signals are conducted by members of the ion channel protein superfamily, a set of more than 140 structurally related pore-forming proteins ( $\mathrm{Yu}$ and Catterall, 2004 ). In addition, members of this protein superfamily are crucial in maintaining ion homeostasis in the kidney and in many different cell types and participate in calcium signaling pathways in nonexcitable cells. Because of their importance in many aspects of cellular regulation and signal transduction, the voltage-gated ion channels are the molecular targets for a wide range of potent biological toxins, including the gating modifier toxins that alter the kinetics and voltage dependence of their activation and inactivation. This introductory chapter introduces the voltage-gated ion channels, gives an overview of the common features of their structure and function, presents the sodium channel as a primary example of neurotoxin action on ion channels, and describes the voltage-sensor trapping model for gating modifier toxin action, which may be a common mechanism of polypeptide toxin action on ion channels.

\section{Voltage-gated Sodium Channels}

The founding member of the ion channel superfamily in terms of its discovery as a protein is the voltage-gated sodium channel. These channels are responsible for the rapid influx of sodium ions that underlies the rising phase of the action potential in nerve, muscle, and endocrine cells. Neurotoxin labeling, purification and functional reconstitution showed that sodium channels from mammalian brain contain voltage-sensing and pore-forming elements in a single protein complex of one principal $\alpha$ subunit of 220 to $260 \mathrm{kDa}$ and one or two auxiliary $\beta$ subunits of approximately 33 to $36 \mathrm{kDa}$ (Catterall, 1984 ,2000a). The a subunits of sodium channels are composed of four homologous domains that each contain six hydrophobic transmembrane segments (Fig. 1 ). A membrane-reentrant loop between the fifth and sixth (S5 and S6) transmembrane segments forms the narrow extracellular end of the pore while the S6 segments form the intracellular end (Fig. 1A , red). The pore is formed in the center of a pseudosymmetric array of the four domains, and a single a subunit containing four domains is able to receive voltage signals and activate its intrinsic pore. The channel responds to voltage by virtue of its $\mathrm{S} 4$ segments ( Fig. 1A, green), which contain repeated motifs of a positively charged amino acid residue followed by two hydrophobic residues, and move outward under the influence of the membrane electric field to initiate a conformational change that opens the pore. Nine voltage-gated sodium channel $\alpha$ subunits, designated $\mathrm{Na}_{\mathrm{V}} 1.1$ to $\mathrm{Na}_{\mathrm{V}} 1.9$ have been functionally characterized. They comprise a single family of proteins with greater than $70 \%$ amino acid sequence identity in their transmembrane segments (Goldin et al., 2000 ). 
Sodium channel auxiliary subunits, $\mathrm{Na}_{\mathrm{V}} \beta 1$ to $\mathrm{Na}_{\mathrm{V}} \beta 4$, interact with the different $\alpha$ subunits and alter their physiological properties and subcellular localization. These proteins have a single transmembrane segment, a large N-terminal extracellular domain that is homologous in structure to a variable chain (V-type) immunoglobulin-like fold, and a short C-terminal intracellular segment (Fig. 1B ) (Isom et al., 1992 ; Isom et al., 1995 ; Morgan et al., 2000 ; Yu et al., 2003 ). The $\mathrm{Na}_{\mathrm{v}} \beta$ subunits interact with a subunits through their extracellular Ig-fold domains, modulate a subunit function, and enhance their cell surface expression (McCormick et al., 1999 ). Like other proteins with an extracellular Ig-fold, they also serve as cell adhesion molecules by interacting with extracellular matrix proteins, cell adhesion molecules, and cytoskeletal linker proteins (Ratcliffe et al., 2000 ; Srinivasan et al., 1998 ; Ratcliffe et al., 2001 ; Kazarinova-Noyes et al., 2001 ; Malhotra et al., 2002 ). The $\mathrm{Na}_{\mathrm{V}} \beta$ subunits are a recent evolutionary addition to the family of ion channel associated proteins, as they have only been identified in vertebrates.

\section{Voltage-gated Calcium Channels}

Voltage-gated calcium channels are the key signal transducers of electrical signaling, converting depolarization of the cell membrane to an influx of calcium ions that initiates contraction, secretion, neurotransmission, and other intracellular regulatory events (Catterall, $2000 \mathrm{~b}$ ). Skeletal muscle calcium channels first identified by drug labeling, purification, and functional reconstitution have a principal $\alpha 1$ subunit of 212 to $250 \mathrm{kDa}$, which is similar to the sodium channel a subunit (Takahashi et al., 1987 ; Tanabe et al., 1987 ). cDNA cloning and sequencing showed that the $\alpha 1$ subunit of calcium channels is analogous to the sodium channel a subunits in structural organization ( Fig. 1A ) and is approximately $25 \%$ identical in amino acid sequence in the transmembrane regions. The a 1 subunit is associated with auxiliary $\alpha 2 \delta, \beta$, and $y$ subunits that are unrelated to the sodium channel auxiliary subunits (Fig. 1B ). As for the sodium channel $\alpha$ subunit, the calcium channel $\alpha 1$ subunit is sufficient to form a voltage-gated calcium-selective pore by itself. Ten functional calcium channel $\alpha 1$ subunits are known in vertebrates, and they fall into three subfamilies that differ in function and regulation (Ertel et al., 2000 ). The Ca 1 subfamily $\left(\mathrm{Ca}_{\mathrm{V}} 1.1\right.$ to $\left.\mathrm{Ca}_{\mathrm{V}} 1.4\right)$ conduct L-type calcium currents that initiate contraction, endocrine secretion, and synaptic transmission at the specialized ribbon synapses involved in sensory input in the eye and ear (Hofmann et al., 1994 ; Striessnig, 1999 ). L-type calcium currents also are important regulators of gene expression and other intracellular processes. They are blocked by the classical calcium channel antagonists, including dihydropyridines, benzothiazepines, and phenylalkylamines. The $\mathrm{Ca}_{\mathrm{V}} 2$ subfamily of calcium channels $\left(\mathrm{Ca}_{\mathrm{V}}\right.$ 2.1 to $\mathrm{Ca}_{\mathrm{V}} 2.3$ ) conduct N-, P/Q- and R-type calcium currents that initiate fast synaptic transmission at synapses in the central and peripheral nervous systems and are blocked specifically by peptide neurotoxins from spider and cone snail venoms (Snutch and Reiner, 1992 ; Dunlap et al., 1995 ; Catterall, 2000 b Olivera et al., 1994$)$. The $\mathrm{Ca}_{\mathrm{V}} 3$ subfamily of calcium channels $\left(\mathrm{Ca}_{\mathrm{V}} 3.1\right.$ to $\left.\mathrm{Ca}_{\mathrm{V}} 3.3\right)$ conduct T-type calcium currents that are important for repetitive action potential firing of neurons in the brain and in the pacemaker cells of the sino-atrial node in the heart (Perez-Reyes, 2003 ). The protein-protein interactions as well as the functional and regulatory properties of different subfamilies of these ion channels are adapted to their distinct roles in electrical signaling and cellular signal transduction.

$\mathrm{Ca}_{\mathrm{V}} 1$ and $\mathrm{Ca}_{\mathrm{V}} 2$ channels have four distinct auxiliary subunits, $\mathrm{Ca}_{\mathrm{V}} \alpha 2, \mathrm{Ca}_{\mathrm{V}} \beta, \mathrm{Ca}_{\mathrm{V}} \mathrm{\gamma}$, and $\mathrm{Ca}_{\mathrm{V}} \delta$ (Fig. 1B ) (Takahashi et al., 1987 ; Catterall, 2000b ), which each comprise a small protein family. The $\mathrm{Ca}_{\mathrm{V}} \alpha 2$ and $\mathrm{Ca}_{\mathrm{V}} \delta$ subunits are encoded by the same gene (Ellis et al., 1988 ), whose translation product is proteolytically cleaved and disulfide linked to yield the mature extracellular $\alpha 2$ subunit glycoprotein of $140 \mathrm{kDa}$ and transmembrane disulfide-linked $\delta$ subunit glycoprotein of $27 \mathrm{kDa}$ (De Jongh et al., 1990 ). Four Ca $\mathrm{v}_{\mathrm{v}}$ a2 genes are known ( Arikkath and Campbell, 2003 ). The four $\mathrm{Ca}_{\mathrm{v}} \beta$ subunits are all intracellular proteins with a common pattern of alpha helical and unstructured segments (Ruth et al., 1989 ; Arikkath and Campbell, 2003 ). They have important regulatory effects on cell surface expression and they also modulate the gating of calcium channels, causing enhanced activation upon depolarization and altered rate and voltage dependence of inactivation (Arikkath and Campbell, 2003 ). Recent structural modeling and x-ray crystallography studies have revealed that these subunits contain conserved, interacting SH3 and guanylate kinase domains like the MAGUK family of scaffolding proteins (Van Petegem et al., 2004 ; Chen et al., 2004 ; Opatowsky et al., 2004 ; McGee et al., 2004 ; Takahashi et al., 2004 ), and therefore may interact with other intracellular proteins. Eight $\mathrm{Ca}_{\mathrm{v}} \mathrm{y}$ subunit genes encode glycoproteins with four transmembrane segments (Jay et al., 1990 ; Arikkath and Campbell, 2003 ). Although the $\mathrm{Ca}_{\mathrm{V}} \mathrm{Y} 1$ subunit is associated specifically with skeletal muscle Ca 1.1 channels, other $\mathrm{Ca}_{\mathrm{V}} \mathrm{Y}$ subunits interact with other calcium channels, glutamate receptors and possibly with other membrane signaling proteins (Arikkath and Campbell, 2003 ). Thus, the $y$ subunits discovered as components of calcium channels apparently have a more widespread role in assembly and cell surface expression of other membrane signaling proteins.

\section{Voltage-gated Potassium Channels}

Voltage-gated potassium channels are activated by depolarization, and the outward movement of potassium ions through them repolarizes the membrane potential to end action potentials, hyperpolarizes the membrane potential immediately following action potentials, and plays a key role in setting the resting membrane potential. In this way, potassium channels control electrical signaling in excitable cells and regulate ion flux and calcium transients in nonexcitable cells. The first voltage-gated potassium channels were cloned from Drosophila based on a mutation that causes the Shaker phenotype (Tempel et al., 1987 ; Papazian et al., 1987 ; Jan and Jan, 1997 ). They are composed of four transmembrane subunits that each is analogous to a single domain of the principal subunits of sodium or calcium channels (Fig. 1A ). The voltage-gated potassium channels are remarkable for their diversity. They include 40 different channels 
that are classified into 12 distinct subfamilies based on their amino acid sequence homology $\left(\mathrm{K}_{\mathrm{V}} 1\right.$ to $\left.\mathrm{K}_{\mathrm{V}} 12\right)$ (Gutman et al., 2003 ). These a subunits can assemble into homo- and hetero-tetramers, leading to a wide diversity of different channel complexes. The diversity of potassium channels allows neurons and other excitable cells to precisely tune their electrical signaling properties by expression of different combinations of potassium channel subunits.

$\mathrm{K}_{\mathrm{V}} 1$ channels are often associated with one of three intracellular $\mathrm{K}_{\mathrm{V}} \beta$ subunits $\left(\mathrm{K}_{\mathrm{V}} \beta 1-3\right)$ (Fig. 1B ) (Scott et al., 1993 ; Rettig et al., 1994 ; Pongs et al., 1999 ), which interacts with the N-terminal T1 domain and forms a symmetric tetramer on the intracellular surface of the channels (Gulbis et al., 2000 ). The $\mathrm{K}_{\mathrm{V}} \beta$ subunits are superficially similar to the $\mathrm{Ca}_{\mathrm{v}} \beta$ subunits in their cytoplasmic location, but are not related in amino acid sequence or structure. The N-terminus of $K_{v} \beta$ subunits of vertebrates serves as an inactivation gate for $K_{V} 1 \alpha$ subunits (Pongs et al., 1999 ), and is thought to enter the pore and block it during sustained channel opening (Zhou et al., 2001 ). This is a unique example of a direct physical role for an auxiliary subunit in channel gating, rather than modulating the gating process of its associated pore-forming a subunit. $\mathrm{K}_{\mathrm{V}} 4$ channels interact with the $\mathrm{K}$ channel interacting proteins KChIp1-4 (Fig. 1B ), which are members of the neuronal calcium sensor family of calmodulin-like calcium regulatory proteins and have four EF hand motifs (An et al., 2000 ). The KChIps enhance expression of $\mathrm{K}_{\mathrm{V}} 4$ channels and modify their functional properties by binding to a site in the intracellular T1 domain, similar to the interaction of $\mathrm{K}_{\mathrm{V}} \beta$ subunits with $\mathrm{K}_{\mathrm{V}} 1$ channels. The $\mathrm{K}_{\mathrm{V}} 7, \mathrm{~K}_{\mathrm{V}} 10$, and $\mathrm{K}_{\mathrm{V}} 11$ channels associate with a different type of auxiliary subunit, the minK-like subunits. These five closely related proteins have a single transmembrane segment and small extracellular and intracellular domains (Takumi et al., 1988 ; Abbott et al., 2001b ). Although these subunits are topologically similar to $\mathrm{Na}_{\mathrm{v}} \beta$ and $\mathrm{Ca}_{\mathrm{v}} \delta$ subunits, they do not have significant amino acid sequence similarity. The minK-like subunits are important regulators of $\mathrm{K}_{\mathrm{v}} 7$ channel function (Sanguinetti et al., 1996 ; Barhanin et al., 1996 ), and mutations in one of these auxiliary subunits causes a form of familial long QT syndrome, which predisposes to dangerous cardiac arrhythmias (Abbott et al., 2001a ). In addition, recent work indicates that these subunits also associate with $\mathrm{K}_{\mathrm{v}} 3$ and $\mathrm{K}_{\mathrm{v}} 4$ channels and are responsible for a form of inherited periodic paralysis (Abbott et al., 2001a ; Zhang et al., 2001 ). In light of this work, it is possible that all $\mathrm{K}_{\mathrm{V}}$ channels associate with minK-related subunits. If this hypothesis is true, the $\mathrm{K}_{\mathrm{V}}$ channels would then resemble the $\mathrm{Na}_{\mathrm{V}}$ and $\mathrm{Ca}_{\mathrm{V}}$ channels in having an associated subunit with a single transmembrane segment and short intracellular and extracellular domains.

\section{Common Aspects of Ion Channel Structure and Function}

The functions of the voltage-gated ion channel proteins can be divided into three complementary aspects: ion conductance, pore gating, and regulation. All members of the family share a common pore motif, with variations appropriate to determine their different ion selectivity. It is likely that this pore motif first evolved in the bacterial ion channels that resemble vertebrate inward rectifiers. The $\mathrm{x}$-ray crystal structure of one of these channels showed that the narrow outer mouth of the pore is formed by the pore loops between the M1 and M2 segments that are analogous to the S5 and S6 transmembrane segments of the 6-TM family members while the length of the pore is formed by a tilted bundle, "inverted teepee" arrangement of the M2 segments (Doyle et al., 1998 ; Fig. 2 ). This structure suggests that the pore is closed at its intracellular end and discriminates ions at the narrow ion selectivity filter at its extracellular end. This model of pore formation fits well with a wealth of structure-function data on the voltage-gated ion channels and the cyclic nucleotide-gated channels. The closure of the pore at the intracellular end suggests that this is the site of pore gating. Support for this idea comes from recent work. The structure of a calcium-activated bacterial potassium channel with calcium bound shows that the crossing of the M2 segments at the intracellular end of the pore is opened by bending of the helix at a highly conserved hinge glycine residue, consistent with the hypothesis that this is the mechanism of pore opening in two-transmembrane-segment bacterial potassium channels (Fig. 2 ) (Jiang et al., 2002b ; Jiang et al., 2002a ) and this conclusion is further supported by mutagenesis studies of six-transmembrane bacterial sodium channels in which substitution of proline for the hinge glycine to favor bending in that position greatly stabilizes the activated state of the channel ( Zhao et al., 2004 ). A similar pore structure is present in the voltage-gated potassium channel $\mathrm{K}_{\mathrm{V}} 1.2$, which appears to have crystallized in an open state (Long et al., 2005 ; Fig. 2 ).

The opening and closing of the voltage-gated sodium, calcium, and potassium channels are primarily gated by changes in membrane potential (Armstrong, 1975 ), which cause movement of gating charges across the membrane and drive conformational changes that open and close the pore (Armstrong, 1981 ). Their voltage-sensing and voltage-dependent gating depends on the S1 to S4 segments of these channels, which can be viewed as an evolutionary addition to the pore-forming segments. The detailed mechanism of voltage-dependent gating remains unknown, but extensive structure-function studies, $x$-ray crystallography, and molecular modeling provide a progressively clearer picture. The positively charged S4 segments are thought to undergo outward and rotational movement through the protein structure during the gating process, as proposed in the 'sliding helix' and 'helical screw' models of gating (Catterall, 1986 ; Guy and Seetharamulu, 1986 ). This movement has been detected in fluorescent labeling experiments (Bezanilla, 2000 ), and the S4 voltage sensor is oriented across the membrane with its gating charges in an outward position in the structure of a $\mathrm{K}_{\mathrm{V}}$ channel with its pore open (Long et al., 2005 ; Fig. 2 ). Remarkably, the S1-S4 voltage sensor domain interacts with the S5-S6 pore domain of the adjacent subunit or domain in the three-dimensional structure of voltage-gated channels (Long et al., 2005 ; Fig. 2 ). A recent structural model of the gating process at the atomic level gives a detailed view of the sliding helix movement of the $\mathrm{S} 4$ gating charges through a gating pore across the membrane upon depolarization and shows how the S4-S5 linker exerts a force on the pore-lining S6 segments to open the pore (Yarov-Yarovoy et al., 2006 
). Altogether, these results nicely define the structure of the open channel with its activated voltage sensor and provide a detailed model for the closed state and the gating movements that activate the channel. These molecular movements are the targets for the action of gating modifier toxins.

\section{Neurotoxins and Sodium Channels}

Sodium channels are unique in that they are the molecular targets for several groups of neurotoxins, which strongly alter channel function by binding to several different receptor sites (Catterall, 1980 ; Cestèle and Catterall, 2000). Due to their high affinity and specificity, neurotoxins provide powerful tools to study the structure and the function of sodium channels, affecting both permeation and gating properties. Six different neurotoxin receptor sites have been identified on voltage-gated sodium channels (Table 1 ). Early pharmacological studies led to the conclusion that neurotoxins act at four distinct receptor sites and have primary effects on either ion permeation or voltage-dependent gating (Table 1 ; Catterall, 1980 ; Martin-Eauclaire et al., 1992 ; Cestèle and Catterall, 2000). Subsequent studies provided evidence for site 5 (Catterall and Risk, 1981 ; Poli et al., 1986 ; Lombet et al., 1987 ) and site 6 (Fainzilber et al., 1994 ). The receptor sites at which neurotoxins affect gating were found to be allosterically coupled, suggesting that conformational changes induced by neurotoxin binding alter the equilibrium between the open and the closed/inactivated states and also alter conformation and toxin binding affinity at other neurotoxin receptor sites (Catterall, 1977, 1980 ).

\section{Pore-blocking Toxins}

Neurotoxin receptor site 1 on sodium channels is occupied by two different groups of toxins: the water soluble heterocyclic guanidines tetrodotoxin (TTX) and saxitoxin (STX) and the peptidic toxins $\mu$-contoxins. TTX is isolated from the tissues of at least 40 species of puffer fish (Fuhrman, 1967 ), but it is also found in molluscs, crabs, octopus, fish and Central American frogs (Yamasuto et al., 1986 ; Mebs et al., 1989 ; Hwang et al., 1991 ). STX is produced by the marine dinoflagellate Gonyaulax catenella and can be found in bivalves such as clams and mussels that feed on the dinoflagellates (Schantz, 1986 ). $\mu$-Conotoxins are isolated from the venom of Conus geographus and related cone snails (Cruz et al., 1985 ; Sato et al., 1983 ). By binding to neurotoxin receptor site 1, these toxins block sodium conductance (Narahashi et al., 1964 ; Hille, 1968 , 1975 ; Narahashi, 1974 ; Ritchie and Rogart, 1977 ). The amino acid residues that form neurotoxin receptor site 1 are located in the pore loop and are thought to form the ion selectivity filter (Noda et al., 1989 ; Terlau et al., 1990; Heineman et al., 1992 ; Fig. 3 ). Surprisingly, selective pressure from the presence of STX in the natural environment or TTX in prey can select for mutations in the ion selectivity filter that cause resistance to these toxins in in the softshell clam Mya arenaria and in garter shakes (Bricelj et al., 2005 ; Geffeney et al., 2005). Although binding experiments have shown that $\mu$-conotoxins inhibit TTX/STX binding on native sodium channels competitively (Moczydlowski et al., 1986 ; Ohizumi et al., 1986 ; Yanagawa et al., 1986 ), some of the mutations that affect TTX affinity do not alter $\mu$-conotoxin binding, suggesting that these two toxins share an overlapping but not identical receptor site (Dudley et al., 1995 ; Stefan et al., 1994 ; Chahine et al., 1995 , 1998 ). Moreover, recent studies of a toxin from the South American spider Phoneutria nigriventer showed that it blocks sodium currents in a state-dependent manner and competes for binding with $\mu$-conotoxins but not with TTX (Martin-Moutot et al., 2006 ). Localization of TTX/STX and $\mu$-conotoxins receptor sites has been instrumental in identifying the pore loop and in clarifying the regions of the channel structure involved in the ion selectivity filter, and one can anticipate that mapping the sites of interaction of P. nigriventer toxin will provide further insight into these overlapping toxin binding sites and their relationship to the ion selectivity filter.

\section{Gating Modifier Toxins Binding to Intramembrane Receptor Sites \\ Neurotoxin receptor site 2}

Lipid-soluble grayanotoxins (found in rhododendron and other plants of the family Ericaceae), the alkaloids veratridine (from the family of Liliaceae ), acotinine (from the plant Acotinum napellus ) and batrachotoxin (from the skin of the Colombian frog Phyllobates aurotaenia ) bind to receptor site 2. These toxins bind preferentially to the activated state of sodium channels and cause persistent activation at resting membrane potential via an allosteric mechanism that leads to block of sodium channel inactivation and shift of the voltage dependence of activation to more negative potentials (Ulbricht, 1969 ; Albuquerque et al., 1971 ; Catterall, 1977 , 1980 ; Khodorov et al., 1985 ).

Photolabelling experiments using batrachotoxin derivatives have localized neurotoxin receptor site 2 to the S6 transmembrane region of domain I of the sodium channel a subunit (Trainer et al., 1996 ). Site-directed mutagenesis has identified several molecular determinants of batrachotoxin binding and action in transmembrane segments IS6 (I433, N434 and L437 of $\mathrm{Na}_{\mathrm{V}}$ 1.4, Wang and Wang, 1998 ) and IVS6 (F1579 and N1584 in $\mathrm{Na}_{\mathrm{V}}$ 1.4, Wang et al., 1999 ; I1760 and F1764 (equivalent to F1579) in $\mathrm{Na}_{\mathrm{V}}$ 1.2, Linford et al., 1998 ) (Fig. 2 ). As for batrachotoxin, grayanotoxin binding affinity is also reduced by mutations of I433, N434, L437, I1575, F1579 on skeletal muscle $\mathrm{Na}_{\mathrm{V}}$ 1.4 channels and the mutations of the corresponding residues on cardiac sodium channels (Ishii et al., 1999 ). However, mutation of Y1586 in transmembrane segment IVS6, which does not alter batrachotoxin binding, completely eradicated grayanotoxin effect on $\mathrm{Na}_{\mathrm{V}} 1.4$ 
channels (Kimura et al., 2000 ). These results indicate that the grayanotoxin receptor site shares overlapping but not identical molecular determinants with batrachotoxin in transmembrane segment IVS6 and has common molecular determinants in transmembrane segment IS6 (Table 1 ).

Involvement of IS6 and IVS6 transmembrane segments in the formation of receptor site 2 suggests that these toxins conform to a domain-interface' allosteric model of ligand binding and action (Fig. 2 ), as initially proposed for binding of calcium channel antagonists ( Catterall and Striessnig, 1992 ; Hockerman et al., 1997 ). It is proposed that the block of inactivation induced by this group of toxins is due to their interaction with the IVS6 transmembrane segment that is required for fast inactivation. Batrachotoxin binding to IVS6 segment may allow the toxin to alter the voltage-dependent movements of the adjacent IVS4 voltage-sensor and thereby affect both activation and coupling of activation to inactivation (Linford et al., 1998 ).

\section{Neurotoxin receptor site 5}

Like batrachotoxin and the other toxins acting at receptor site 2, the lipid-soluble toxins brevetoxin and ciguatoxin originating from the dinoflagellates Karenia brevis (formerly Gymnodinium breve or Ptychodiscus brevis ) and Gambierdicus toxicus , respectively, enhance sodium channel activity. They bind to neurotoxin receptor site 5 and cause a shift in activation to more negative membrane potentials and a block of inactivation (Catterall and Risk, 1981 ; Huang et al., 1984 ; Poli et al., 1986 , Benoit et al., 1986 ; Lombet et al., 1987 ). Transmembrane segments IS6 and IVS5 have both been identified to participate in the formation of neurotoxin receptor site 5 in photoaffinity labeling experiments (Trainer et al., 1991 , 1994 ; Fig. 3 ). Binding determinants for brevetoxin seem to be widely dispersed throughout these transmembrane segments (Konoki, Linford, Scheuer, and Catterall, unpublished). From a structural point of view, these results indicate that transmembrane segments IS6 and IVS5 are in close proximity in the native sodium channels and interact to form this receptor site (Trainer et al., 1991,1994 ), which is confirmed by the recent structure of $\mathrm{K}_{\mathrm{V}} 1.2$ channels (Long et al., 2005 ).

\section{Allosteric modulation of sodium channel function}

The lipid soluble toxins that act at neurotoxin receptor sites 2 and 5 on sodium channel are allosteric modulators of channel function. They bind at sites that are distinct from the pore or the voltage sensors and favor the open state of the sodium channel through indirect, allosteric interactions. The initial proposal for this mechanism of toxin action came from studies of persistent activation of sodium channels by the lipid soluble toxins (Catterall, 1977, 1980). These studies showed that the toxins act as full or partial agonists in causing persistent activation of sodium channels and that their effects can be quantitatively fit by an allosteric model, which assumes that they bind with high affinity to activated sodium channels and thereby shift a conformational equilibrium toward the activated state. Additional support for this mechanism of action comes from the pleiotropic effects of these toxins-negative shift of activation, block of inactivation, and in some cases altered ion permeation. We propose that these toxins alter the interactions of transmembrane segments within homologous domains as well as between adjacent homologous domains, resulting in alteration of voltage-dependent activation, its coupling to inactivation, and in some cases even ion permeation.

\section{Polypeptide Gating Modifier Toxins Binding to Extracellular Receptor Sites \\ Neurotoxin receptor site 3}

Neurotoxin receptor site 3 of sodium channels is occupied by several groups of polypeptide toxins: a-scorpion toxins, sea-anemone toxins and some spider toxins. These toxins slow or block sodium channel inactivation (Narahashi, 1974 ; Bergman et al., 1976 ; Catterall, 1979 , 1980 ; Catterall and Beress, 1978 ; Couraud et al., 1978 ; Schweiz et al., 1981 ; Lazdunski et al., 1986 ; Strichartz et al., 1987 ; Nicholson et al., 1994,1998 ). Alpha-scorpion toxins are a family of structurally and functionally related polypeptides neurotoxins, each containing 60 to 70 amino acid residues cross-linked by four disulfide bonds (Kopeyan et al., 1974 ; Rochat et al., 1979 ). They have complex phylogenetic and structure-function relationships, especially when toxins selective for mammals versus insects are considered ( Rodriguez de la Vega and Possani, 2005 ). In this review, we have used the traditional nomenclature for the two main classes of scorpion toxins that are active on mammals-the $\alpha$-scorpion toxins that slow inactivation and the $\beta$-scorpion toxins that enhance activation (Table 1 ; Dufton and Rochat, 1984 ).

Neurotoxin receptor site 3 was first identified on mammal sodium channels using a-scorpion toxins (Catterall, 1976; Couraud et al., 1978 ). The binding affinity of this group of toxins for receptor site 3 is decreased by depolarization on rat brain sodium channels ( Catterall, 1977b ; Catterall and Beress, 1978 ). The voltage dependence of binding correlates closely with the voltage dependence of channel activation (Catterall, 1979 ). Therefore, the specific action of these toxins on inactivation implies that membrane potential affects the structure of receptor site 3 on rat brain sodium channels, that this region of the channel is important for coupling of activation and inactivation, and that toxin binding prevents the conformational change required for fast inactivation (Catterall, 1979 ).

Localization of receptor site 3 was first investigated by photoaffinity labeling, cleavage with proteases or cyanogens bromide, and antibody mapping with sequence-specific antibodies and by block of binding with sequence-specific antibodies (Tejedor et al., 1988 , Thomsen et al., 1989 ). These results suggested that the extracellular loops between transmembrane segments S5 and S6 in domains I and 
IV of the $\alpha$-subunit are involved in binding of $\alpha$-scorpion toxins. Subsequent site-directed mutagenesis studies further identified individual amino acid residues in the extracellular loop connecting the S3 and S4 segments in domain IV, which appear to be essential for both binding and action of these toxins (Rogers et al., 1996 ). Since basic amino acid residues of the toxins are known to be implicated in the interaction with the channels (Habersetzer-Rochat and Sampieri, 1976 ; El Ayeb et al., 1986 ; Kharrat et al., 1989 ; Gallagher and Blumenthal, 1994 ; Khera et al., 1994), it is of interest that E1613 was identified as a major determinant for both a-scorpion toxin and sea-anemone toxin binding (Table 1 ; Rogers et al., 1996 ). Likewise, the mutation of the homologous residue in cardiac (D1612) and skeletal muscle (D1428) sodium channels alters the binding of sea-anemone toxins (Benziger et al., 1998 ). Extensive mutagenesis in the loop S3-S4 of domain IV of rat brain sodium channels indicated that interaction of $\alpha$-scorpion toxin and sea-anemone toxin required overlapping but distinct molecular determinants on the channel. a-Scorpion toxin affinity is increased by mutations K1617A and P1622A; sea-anemone toxin affinity is increased by mutations L1614A, K1617A and S1621A and decreased by mutations E1616A, V1620A and L1624A (Table 1 ; Rogers et al., 1996 ). Thus, as suggested previously by binding experiments (Catterall and Beress, 1978 ; Couraud et al., 1978 ), a-scorpion toxins and sea-anemone toxins share overlapping receptor sites (Rogers et al., 1996 ).

Location of neurotoxin receptor site 3 just on the extracellular side of transmembrane segment IVS4 suggested a molecular mechanism for toxin action (Rogers et al., 1996 ). The S4 segments of sodium channels serve as voltage sensors, moving outward under the influence of the electric field when the membrane is depolarized. Therefore, $\alpha$-scorpion toxins and sea-anemone toxins are proposed to slow sodium channel inactivation by preventing the outward movement of the IVS4 transmembrane segment, thereby preventing conformational changes that are necessary for fast inactivation (Rogers et al., 1996 ). Prolonged depolarization forces the outward movement of the IVS4 segment and causes voltage-dependent dissociation of the bound $\alpha$-scorpion toxins (Catterall, 1977b ). This mechanism of action is supported by recent evidence that a-scorpion toxins prevent a component of outward gating charge movement that is associated with inactivation of the channel (Sheets et al., 1999 ). This voltage-sensor trapping model of toxin action has wide applicability to peptide gating modifier toxins (see below).

\section{Neurotoxin receptor site 4}

Neurotoxin receptor site 4 is occupied by another group of scorpion toxins: the $\beta$-scorpion toxins. They are composed of $60-65$ amino acid residues crosslinked by four disulfide bridges (Rochat et al., 1979 ; Dufton and Rochat, 1984 ). $\beta$-scorpion toxins induce both a shift in the voltage dependence of sodium channel activation in the hyperpolarizing direction and a reduction of the peak sodium current amplitude (Cahalan, 1975 : Jover et al., 1980 ; Jaimovich et al., 1982 ; Meves et al., 1982 ; Wang and Strichartz, 1983 ; Vijverberg et al., 1984 ; Jonas et al., 1986 ). Recently, Magi toxin 5 from the spider Macrothele gigas has also been shown to bind to neurotoxin receptor site 4, the first spider toxin to have this activity (Corzo et al., 2003 ).

In order to localize receptor site 4, chimeric sodium channels were used. Analysis of the activity of $\beta$-scorpion toxins on chimeric sodium channels, having a combination of domains from cardiac and skeletal muscle or brain sodium channels indicated that domain II is required for binding (Marcotte et al., 1997 ) and that specific amino acid residues in the extracellular loops connecting the S1-S2 and S3S4 segments are primarily responsible (Cestèle et al., 1998 ; Fig. 3 ). In fact, the single residue chimeric mutation G845N strongly decreased the affinity of the toxin for its receptor site on rat brain sodium channels and markedly altered the electrophysiological effects of $\beta$-scorpion toxins. No negative shift in the voltage-dependence of activation was observed for this mutant. Thus, the change of G845 to N is responsible for most of the difference of affinity between the brain and cardiac isoforms and also for the absence of effect of $\beta$-scorpion toxin on voltage-dependent activation of the cardiac sodium channel (Cestèle et al., 1998 ).

These results provide new insight into the mode of action of $\beta$-scorpion toxins on sodium channels. The voltage dependence of activation of the brain sodium channels is modified by $\beta$-scorpion toxin only after a strong depolarizing prepulse. Therefore, the interaction of the toxin with its receptor site must be dependent on the activated conformational state of the toxin receptor site. Evidently, binding of $\beta$ -scorpion toxins to this high affinity conformation is disturbed by the mutation G845N. The proposed mechanism of action of $\beta$-scorpion toxins on sodium channels therefore involves interaction with the extracellular end of the IIS4 segment in activated sodium channels through binding to the S3-S4 loop. Since the IIS4 segment moves outward during depolarization, it is proposed that the toxin binds to newly accessible residues in the IIS3-S4 loop and the extracellular end of the IIS4 segment during the conditioning prepulse. By binding to the extracellular end of the IIS4 segment, $\beta$-scorpion toxins are proposed to trap and stabilize the IIS4 segment in its outward, activated position, thereby enhancing channel activation in response to subsequent depolarization and negatively shifting the voltage dependence of activation (Cestèle et al., 1998 ).

$\beta$-scorpion toxins are macromolecular ligands and, like $\alpha$-scorpion toxins (Tejedor et al., 1988 ; Thomsen et al., 1989 ), may be expected to have additional points of contact with the extracellular domains of sodium channels in addition to their binding site in the IIS3 -S4 linker. The first evidence for this has recently come from studies of the specificity of interaction of the $\beta$-scorpion toxin Tz1 from Tityus zulianus (Leipold et al., 2006 ), in which three amino acid residues in the C-terminal pore loop in domain III was shown to determine the specificity for $\beta$-scorpion toxin action on different sodium channel subtypes. Because the voltage sensor domain (segments $\mathrm{S} 1$ to S4) of one $\mathrm{K}_{\mathrm{V}} 1.2$ channel subunit interact with the pore domain (S5 and S6 segments and the P loop) of the adjacent subunit in 
clockwise rotation, this novel interaction is consistent with the probable structure of the sodium channel in which the S1 to S4 segments of domain II should interact with the S5 to S6 segments and P loop of domain III.

\section{Neurotoxin receptor site 6}

$\delta$-conotoxins bind at neurotoxin receptor site 6 and slow sodium channel inactivation (Fainzilber et al., 1994 ), as indicated in Table 1 . Recent structure-function studies indicate that $\delta$-conotoxins interact with a set of amino acid residues in the IVS4 segment, near the neurotoxin receptor site 3 (Leipold et al., 2005 ). Their binding and action is synergistic with $\alpha$-scorpion toxins, probably because both of these toxins trap the IVS4 voltage sensor in a similar conformation (see the voltage-sensor trapping model below). These results suggest that the $\delta$-conotoxins may slow inactivation by the same molecular mechanism as $\alpha$-scorpion toxins, sea-anemone toxins, and spider toxins.

\section{Voltage-Sensor Trapping-A Common Mechanism of Action of Polypeptide Gating Modifier Toxins}

\section{The voltage-sensor trapping mechanism}

Studies on sodium channels indicate that polypeptide neurotoxins from scorpions and sea anemones have evolved to use a novel voltage-sensor trapping mechanism to alter channel gating (Rogers et al., 1996 ; Cestèle et al., 1998 , 2001 ). The voltage sensors responsible for sodium channel activation and its coupling to inactivation are transmembrane segments, inaccessible to binding of hydrophilic polypeptide toxins. To alter gating, these toxins have evolved to bind to the S3-S4 loop at the extracellular ends of the S4 segments of sodium channels and impede their transmembrane movements that are required in the gating process. Thus, $\alpha$-scorpion toxins and sea-anemone toxins specifically block inactivation by holding the transmembrane segment in domain IV in its inward position, while $\beta$ -scorpion toxins specifically enhance activation of sodium channels by holding the S4 segment in domain II in its outward position. The $\delta$ -atrachotoxins from spider venoms are likely to act by a similar voltage-sensor trapping mechanism. All of these toxins directly alter the movements of a voltage sensor and therefore have quite specific effects on channel function. Evidently, animals from at least two different phyla—coelenterates and arthropods—have independently evolved toxins that act on sodium channels through this mechanism.

In fact, this voltage-sensor trapping mechanism may be the molecular basis for the actions of all polypeptide toxins that alter the voltage dependence of ion channel gating. For example, hanatoxins from tarantula bind to the S3-S4 loop of potassium channels and inhibit channel activation by shifting the voltage dependence of activation to more positive membrane potentials (Swartz et al., 1997 ), and agatoxins from spiders bind to the IVS3-S4 loop of calcium channels and shift their voltage dependence of activation to more positive membrane potential (Bourinet et al., 1999 ; Li-Smerin et al., 1999 ). It is highly likely that they also act by trapping these voltage sensors in their inward, resting positions. We predict that additional polypeptide neurotoxins that alter the voltage dependence of ion channel gating will also be found to bind to S3-S4 loops and act by a 'voltage-sensor trapping' mechanism.

\section{Interaction sites for voltage-sensor trapping}

Several types of gating-modifier toxins that inhibit activation or inactivation bind to their target ion channel through interactions with acidic and hydrophobic amino acid residues in S3-S4 loops, which include a key glutamate residue that is conserved at the extracellular end of the S3 segment (Rogers et al., 1996 ; Cestèle et al., 1998 ; Swartz and MacKinnon, 1997 ; Bourinet et al., 1999 ; Winterfield and Swartz, 2000 ; Li-Smerin and Swartz, 1998, 2000 ).

Scheme 1 illustrates the alignment of the S3-S4 loops in domain IV of $\mathrm{Na}_{\mathrm{V}} 1.2$ channels containing the $\alpha$-scorpion toxin and sea anemone toxin receptor sites, in domain IV of $\mathrm{Ca}_{\mathrm{V}} 2.1$ channels containing the $\omega$-agatoxin receptor site, and in the $\mathrm{K}_{\mathrm{V}} 2.1$ channel containing the hanatoxin and grammotoxin receptor sites. This alignment reveals a common toxin-binding motif at the extracellular end of the $\mathrm{S} 3$ segment composed of 2 hydrophobic residues and 1 acidic residue in the sequence ФФXXE (Scheme 1 , shaded residues).

In contrast, our studies of the receptor site for $\beta$-scorpion toxins have revealed a different interaction motif. Six amino acid residues in loops IIS1-S2 and IIS3-S4 have been identified, whose mutations would reduce the affinity for the $\beta$-scorpion toxin CssIV by 13,650-fold if their effects were additive (Cestèle et al., 1998 , 2006 ). The cumulative effects of these mutations would increase the $\mathrm{K}_{\mathrm{D}}$ for CssIV from $0.2 \mathrm{nM}$ to $2.7 \mu \mathrm{M}$, indicating that these amino acid residues are essential for high-affinity binding of Css IV. Because we have made conservative amino acid substitutions in order to retain protein expression and function, it is likely that the substituted amino acid residues at these critical positions retain a substantial contribution to the residual low-affinity binding of CssIV and therefore that this is a lower limit of their contribution to high affinity binding. The three amino acid residues involved in the formation of the $\beta$-scorpion toxin receptor site on IIS3-S4 linker of $\mathrm{Na}_{\mathrm{v}} 1.2$ channels are quite different in sequence context from those forming the interaction site for $\alpha$-scorpion toxins and the toxins that inhibit calcium and potassium channels (Scheme 1 ). Thus, $\beta$-scorpion toxins are the first group of gating modifier toxins to interact with a different binding motif in the S3-S4 linker, and they are unique in enhancing activation of their target channel. We speculate that this novel mode of interaction is essential for the unique effect of $\beta$-scorpion toxins to trap the voltage sensor in its activated conformation. 


\section{Structural basis for voltage-sensor trapping}

In order to gain insight into the three-dimensional structure of the $\beta$-scorpion toxin/sodium channel complex, we modeled the three-dimensional structure of the toxin-receptor complex with the Rosetta algorithm. This modeling method is informatics-based, using the structures in the Protein Databank to predict the folding of each segment of the protein of interest and then assembling the most favored structure based on all known protein structures (Rohl et al., 2004a , b ). The Rosetta method has been the most accurate in predicting the structures of folded domains in the CASP trials of modeling (Bradley et al., 2005 ; Chivian et al., 2005 ). Moreover, we have recently developed a membrane mode of the Rosetta algorithm that successfully predicts the transmembrane folds of several membrane proteins (Yarov-Yarovoy et al., 2006a , b). We used the three-dimensional structures of related toxins and ion channels to construct a model of the Css IV toxin-sodium channel complex, based on the x-ray crystallographic structure of Centruroides sculpturatus variant II, a structurally related $\beta$-scorpion toxin (Cook et al., 2002 ), and the x-ray crystallographic structure of the related voltage sensor of the bacterial voltage-gated potassium channel, $\mathrm{K}_{\mathrm{V}}$ AP (Jiang et al., 2003 ). This $\mathrm{K}_{\mathrm{V}}$ AP structure was derived from expression and crystallization of the S1 to S4 segments of that channel, and it is likely that this structure represents the activated state of the voltage sensor. We used the Rosetta-Dock algorithm to fit the toxin into the voltage sensor structure, after a manual adjustment of $-10^{\circ}$ in the $\psi$ torsion angle of G822 in the $\mathrm{K}_{\mathrm{V}}$ AP voltage sensor to increase toxin access. The resulting structural model predicts that the CssIV toxin fits tightly into the crevice between the S1-S2 and S3-S4 helical hairpins of the sodium channel IIS1-S4 structure (Fig. 4 ), a position that would fix movements of the S1-S2 and S3-S4 helical hairpins relative to each other.

Our structural model reveals close interactions between amino acid residues in the toxin and sodium channel that have been shown by mutagenesis studies to be important for toxin binding and action. Residues E837 and L840 in the IIS3-S4 loop make productive binding interactions with amino acid residues in the Css IV toxin (Fig. 4 ). E837 forms a salt bridge with R27 and has a secondary charge- $\pi$ interaction with Y24. L840 also interacts with Y24 and secondarily with E28 (Fig. 4 ). Rotating the model 60 ${ }^{\circ}$ reveals E779 in the IIS1-S2 loop, which makes a productive chargeinteractions between two pairs of $\mathrm{E}$ and $\mathrm{L}$ residues initially seemed surprising, interactions between $\mathrm{E}$ and $\mathrm{L}$ are very common in protein-protein interfaces of known structure (Glaser et al., 2001 ) and therefore must be quite favorable for binding interactions. All six of these predicted interactions are consistent with mutagenesis results, as we have found important effects of mutations of E779, E837, and L840 on Css IV binding and action on the sodium channel in this work and Cohen et al. have reported important effects of mutations of L19, Y24, R27, E28, and F44 for binding and toxicity of Css IV (Cohen et al., 2005 ). The close fit between the structural model and the results of mutagenesis studies strongly supports the accuracy of the structure prediction.

Our previous results also demonstrated a crucial role for G845 in the sodium channel. Mutation of this residue to N decreased toxin-binding affinity by 13 -fold and completely prevented voltage sensor trapping, even when high concentrations of toxin were tested ( Cestèle et al., 1998 ). Our model reveals the molecular basis for this strong effect (Fig. 4 ). Even though G845 does not make a productive interaction with CssIV itself, substitution of the much larger $\mathrm{N}$ residue creates a steric conflict with the side chains of N7 and F14 of CssIV, which would reduce toxin binding affinity and potentially prevent voltage sensor trapping. Thus, this correlation also supports the accuracy of our structural model.

In this structure, the interactive face of the $\beta$-scorpion toxin is inserted between the S1-S2 loop and the S3-S4 loop, and the amino acid residues known to be important for binding on the toxin and on the channel interact directly in the binding interface. The crevice formed by the S1-S2 and the S3-S4 helical hairpins of the voltage sensor accommodates all of the interactive surface of the toxin that has been defined by mutagenesis studies, arguing against any other significant interaction sites in the resting state. This mode of interaction allows the toxin to control the relative movement of these two extracellular loops and thereby potentially influence the gating movements of the S4 voltage sensor. Based on this structural model, we propose that movement of the IIS4 segment under the influence of the electric field allows new interactions between the channel and the CssIV toxin. This strengthened toxin-receptor interaction would then stabilize the voltage sensor in its activated conformation and enhance subsequent activation of the sodium channel by negatively shifting its voltage dependence.

\section{Conclusion}

Voltage-gated $\mathrm{Na}^{+}, \mathrm{Ca}^{2+}$, and $\mathrm{K}^{+}$channels are encoded by 60 genes in the human genome, and these channel proteins are the founding members of the larger superfamily of voltage-gated-like ion channels numbering 143 in total (Yu and Catterall, 2004 ). These channels have a common pore motif and a common mechanism for pore opening and voltage-dependent gating. Animals and plants from many phyla have targeted these channels with potent neurotoxins, which paralyze prey by altering electrical signaling. The voltage-gated $\mathrm{Na}^{+}$channel illustrates this diversity of toxin action, with six receptor sites at which toxins from many different phyla interact and modify channel function. Studies of neurotoxins and $\mathrm{Na}^{+}$channels have revealed three broad classes of toxin action (Catterall, 1980 ; Cestèle and Catterall, 2000). Pore-blocking toxins bind in the transmembrane pore and physically occlude it, thereby preventing ion conductance. Lipid-soluble gating-modifier toxins acting at intramembrane receptor sites bind preferentially to specific conformations of the channel and stabilize unique functional states via an allosteric mechanism, thereby altering activation, inactivation, and even ion selectivity 
concurrently. Polypeptide gating-modifier toxins acting at extracellularly exposed receptor sites including the S3-S4 linker and modify the voltage-driven gating movements of the S4 transmembrane segments via a voltage-sensor trapping mechanism, thereby enhancing or inhibiting voltage-dependent activation or inactivation. It is likely that these mechanisms defined for $\mathrm{Na}^{+}$channels will be relevant for gating modifier toxins acting on other members of the voltage-gated ion channel family.

\section{References:}

- Abbott GW , Butler MH, Bendahhou S, Dalakas MC, Ptacek LJ , Goldstein SA . 2001a ; MiRP2 forms potassium channels in skeletal muscle with Kv3.4 and is associated with periodic paralysis . Cell . $104: 217-231$

- Abbott GW , Goldstein SA, Sesti F . 2001b ; Do all voltage-gated potassium channels use MiRPs? . Circ Res . 88 : 981 - 983

- Albuquerque EX, Daly JW, Witkop B . 1971 ; Batrachotoxin: chemistry and pharmacology . Science . 172 : 995 - 1002

- An WF, Bowlby MR, Betty M, Cao J, Ling HP , Mendoza G, Hinson JW, Mattsson KI, Strassle BW, Trimmer JS , Rhodes KJ . 2000 ; Modulation of A-type potassium channels by a family of calcium sensors . Nature . $403: 553-556$

- Arikkath J , Campbell KP . 2003 ; Auxiliary subunits: essential components of the voltage-gated calcium channel complex . Curr Opin Neurobiol . 13 : 298 - 307

- Armstrong CM . 1975 ; Ionic pores, gates, and gating currents . Q Rev Biophys . $7: 179$ - 210

- Armstrong CM . 1981 ; Sodium channels and gating currents . Physiol Rev . $61: 644$ - 682

- Barhanin J , Lesage F, Guillemare E, Fink M , Lazdunski M, Romey G . 1996 ; KVLQT1 and lsK (minK) proteins associate to form the I(Ks) cardiac potassium current . Nature . $384: 78-80$

- Benoit E, Legrand AM , Doboid JM . 1986 ; Effects of ciguatoxin on current and voltage clamped frog myelinated nerve fibre . Toxicon . 24 : 357 - 364

- Benzinger GR, Kyle JW , Blumenthal KM , Hanck DA . 1998 ; A specific interaction between the cardiac sodium channel and site-3 toxin anthopleurin B . J Biol Chem . 273 : $80-84$

- Bergman CJ , Dubois JM , Rojas E , Rathmayer W . 1976 ; Decreased rate of sodium conductance inactivation in the nodes of Ranvier induced by polypeptide toxin from sea anemone. Biochim Biophys Acta . $455: 173$ - 184

- Bezanilla F. 2000 ; The voltage sensor in voltage-dependent ion channels. Physiol Rev . 80 : 555 - 592

- Bourinet E, Soong TW, Sutton K, Slaymaker S, Mathews E, Monteil A, Zamponi GW , Nargeot J, Snutch TP . 1999 ; Splicing of alpha 1A subunit gene generates phenotypic variants of P- and Q-type calcium channels . Nat Neurosci . 2 : 407 - 415

- Bradley P , Misura KM , Baker D . 2005 ; Toward high-resolution de novo structure prediction for small proteins . Science . 309 : 1868 - 1871

- Bricelj VM , Connell L, Konoki K, Macquarrie SP, Scheuer T, Catterall WA, Trainer VL . 2005 ; Sodium channel mutation leading to saxitoxin resistance in clams increases risk of PSP . Nature . $434: 763-767$

- Cahalan MD . 1975 ; Modification of sodium channel gating in frog myelinated nerve fibres by Centruroides sculpturatus scorpion venom . J Physiol . 244 : 511 - 534

- Catterall WA, Beress L. 1978 ; Sea anemone toxin and scorpion toxin share a common receptor site associated with the action potential ionophore . J Biol Chem . 253 : 7393 7396

- Catterall WA . 1980 ; Neurotoxins that act on voltage-sensitive sodium channels in excitable membranes . Ann Rev Pharmacol Toxicol . 20 : 15 - 42

- Catterall WA . 1977 ; Membrane potential dependent binding of scorpion toxin to the action potential $\mathrm{Na}^{+}$ionophore . J Biol Chem . $252: 8660$ - 8668

- Catterall WA . 1977 ; Activation of the action potential Na ${ }^{+}$ionophore by neurotoxins. An allosteric model . J Biol Chem . 252 : 8669 - 8676

- Catterall WA . 1979 ; Binding of scorpion toxin to receptor sites associated withe sodium channels in frog muscle . J Gen Physiol . 74 : 375 - 391

- Catterall WA, Risk M . 1981 ; Toxin $\mathrm{T}_{46}$ from Ptychodiscus brevis (formely Gymnodinium breve) enhances activation of voltage-sensitive sodium channels by veratridine . Mol Pharmacol . 19: $345-348$

- Catterall WA . 1984 ; The molecular basis of neuronal excitability . Science . $223: 653-661$

- Catterall WA . 1986 ; Molecular properties of voltage-sensitive sodium channels . Annu Rev Biochem . 55 : 953 - 985

- Catterall WA . 2000a ; From ionic currents to molecular mechanisms: The structure and function of voltage-gated sodium channels . Neuron . 26 : 13 - 25

- Catterall WA . 2000b ; Structure and regulation of voltage-gated calcium channels . Annu Rev Cell Dev Bio . 16 : 521 - 555

- Catterall WA, Striessnig J . 1992 ; Receptor sites for calcium channel antagonists . Trends Pharmacol Sci . 13 : 256 - 262

- Cestèle S, Qu Y, Rogers JC, Rochat H, Scheuer T, Catterall WA . 1998 ; Voltage sensor-trapping: enhanced activation of sodium channels by beta-scorpion toxin bound to the S3-S4 loop in domain II . Neuron . $21: 919$ - 931

- Cestèle S, Scheuer T, Mantegazza M, Rochat H, Catterall WA . 2001 ; Neutralizatioin of gating charges in domain II of the sodium channel a subunit enhances voltage sensor trapping by a $\beta$-scorpion toxin . J Gen Physiol . $118: 291$ - 302

- Cestèle S, Yarov-Yarovoy V, Qu Y, Sampieri F, Scheuer T, Catterall WA . 2006 ; Structure and function of the voltage sensor of sodium channels probed by a $\beta$-scorpion toxin. J Biol Chem . $282: 21332-21344$

- Chahine M, Chen LQ, Fotouhi N, Walsky R, Fry D, Santarelli V, Horn R, Kallen RG . 1995 ; Characterizing the mu-conotoxin binding site on voltage-sensitive sodium channels with toxin analogs and channel mutations. Receptors Channels . $3: 161-174$

- Chahine M, Sirois J, Marcotte P, Chen L, Kallen RG . 1998 ; Extrapore residues of the S5-S6 loop of domain 2 of the voltage-gated skeletal muscle sodium channel (rSkM1) contribute to the mu-conotoxin GIIIA binding site. Biophys J . $75: 236$ - 246

- Chen YH, Li MH, Zhang Y, He LL, Yamada Y, Fitzmaurice A, Shen Y, Zhang H, Tong L, Yang J . 2004 ; Structural basis of the alpha1-beta subunit interaction of voltage-gated calcium channels . Nature . $429: 675-680$

- Chivian D, Kim DE, Malmstrom L, Schonbrun J, Rohl CA, Baker D . 2005 ; Prediction of CASP6 structures using automated Robetta protocols . Proteins . 61 : 157 - 166

- Cohen L, Karbat I, Gilles N, Froy O, Corzo G, Angelovici R, Gordon D, Gurevitz M . 2004 ; Dissection of the functional surface of an anti-insect excitatory toxin illuminates a putative "hot spot" common to all scorpion beta-toxins affecting Na+ channels . J Biol Chem . 279 : 8206 - 8211

- Cohen L, Karbat I, Gilles N, Ilan N, Benveniste M, Gordon D, Gurevitz M . 2005 ; Common features in the functional surface of scorpion beta-toxins and elements that confer specificity for insect and mammalian voltage-gated sodium channels. J Biol Chem . 280 : 5045 - 5053

- Cook WJ , Zell A, Watt DD, Ealick SE . 2002 ; Structure of variant 2 scorpion toxin from Centruroides sculpturatus Ewing . Protein Sci . 11 : 479 - 486

- Corzo G, Gilles N, Satake H, Villegas E, Dai L, Nakajima T, Haupt J . 2003 ; Distinct primary structures of the major peptide toxins from the venom of the spider Macrothele gigas that bind to sites 3 and 4 in the sodium channel . FEBS Lett . $547: 43-50$

- Couraud F , Rochat H , Lissitzki S . 1978 ; Binding of scorpion and sea anemone neurotoxins to a common site related to the action potential Na ${ }^{+}$ionophore in neuroblastoma cells . Biochem Biophys Res Comm . $83: 1525-1530$

- Cruz LJ , Gray WR, Olivera BM, Zeikus RD, Kerr L, Yoshikami D, Moczydlowski E . 1985 ; Conus geographus toxins that discriminate between neuronal and muscle sodium channels . J Biol Chem . $260: 9280$ - 9288

- De Jongh KS , Warner C , Catterall WA . 1990 ; Subunits of purified calcium channels $\alpha 2$ and $\delta$ are encoded by the same gene . J Biol Chem . 265 : 14738 - 14741

- Delori P, Van Rietschoten J, Rochat H . 1981 ; Scorpion venoms and neurotoxins: an immunological study . Toxicon . 19 : 393 - 407

- Doyle DA, Cabral JM , Pfuetzner RA, Kuo AL, Gulbis JM , Cohen SL, Chait BT , MacKinnon R . 1998; The structure of the potassium channel: Molecular basis of potassium conduction and selectivity. Science . $280: 69-77$

- Dudley SC Jr , Todt H , Lipkind G , Fozzard HA . 1995 ; A $\mu$-conotoxin-insensitive $\mathrm{Na}^{+}$channel mutant: possible localization of a binding site at the outer vestibule . Biophys J . $69: 1657-1665$

- Dufton MJ , Rochat H . 1984 ; Classification of scorpion toxins according to amino acid composition and sequence . J Mol Evol . 20 : 120 - 127 
- Dunlap K , Luebke JI, Turner TJ . 1995 ; Exocytotic $\mathrm{Ca}^{2+}$ channels in mammalian central neurons . TINS . 18 : 89 - 98

- El Ayeb M, Darbon H, Bahraoui EM , Vargas O, Rochat H. 1986 ; Differential effects of defined chemical modifications on antigenic and pharmacological activities of a and $\beta$ toxins . Eur J Biochem . 155 : 289 - 294

- Ellis SB , Williams ME, Ways NR, Brenner R, Sharp AH, Leung AT, Campbell KP, McKenna E, Koch WJ , Hui A, Schwartz A, Harpold MM . 1988 ; Sequence and expression of mRNAs encoding the alpha 1 and alpha 2 subunits of a DHP-sensitive calcium channel . Science . $241: 1661$ - 1664

- Ertel EA, Campbell KP, Harpold MM , Hofmann F, Mori Y, Perez-Reyes E, Schwartz A, Snutch TP, Tanabe T, Birnbaumer L, Tsien RW , Catterall WA . 2000 ; Nomenclature of voltage-gated calcium channels . Neuron . $25: 533$ - 535

- Fainzilber M , Kofman O, Zlotkin E, Gordon D . 1994 ; A new neurotoxin receptor site on sodium channels is identified by a conotoxin that affects sodium channel inactivation in molluses and acts as an antagonist in rat brain . J Biol Chem . $269: 2574-2580$

- Fuhrman FA . 1967 ; Tetrodotoxin. It is a powerful poison that is found in two almost totally unrelated kinds of animal: puffer fish and newts It has been serving as a tool in nerve physiology and may provide a model for new local anesthetics . Sci Am . 217:60 - 71

- Gallagher MJ , Blumenthal KM . 1994 ; Importance of the unique cationic residues arginine 12 and lysine 49 in the activity of the cardiotonic polypeptide anthopleurin B . J Biol Chem . $269: 254-259$

- Glaser F, Steinberg DM , Vakser IA, Ben-Tal N . 2001 ; Residue frequencies and pairing preferences at protein-protein interfaces . Proteins . 43 : 89 - 102

- Goldin AL, Barchi RL, Caldwell JH, Hofmann F, Howe JR, Hunter JC, Kallen RG, Mandel G, Meisler MH, Berwald Netter Y, Noda M, Tamkun MM , Waxman SG, Wood JN , Catterall WA . 2000 ; Nomenclature of voltage-gated sodium channels . Neuron . 28 : 365 - 368

- Gulbis JM , Zhou M, Mann S, Mackinnon R . 2000 ; Structure of the cytoplasmic beta subunit-T1 assembly of voltage-dependent potassium channels . Science . 289 : 123 127

- Gutman GA, Chandy KG, Adelman JP, Aiyar J , Bayliss DA, Clapham DE, Covarriubias M, Desir GV , Furuichi K, Ganetzky B , Garcia ML , Grissmer S , Jan LY, Karschin A, Kim D , Kuperschmidt S , Kurachi Y, Lazdunski M, Lesage F, Lester HA, McKinnon D, Nichols CG , O'Kelly I, Robbins J , Robertson GA , Rudy B , Sanguinetti M, Seino S , Stuehmer W , Tamkun MM , Vandenberg CA , Wei A, Wulff H , Wymore RS . 2003 ; International Union of Pharmacology. XLI Compendium of voltage-gated ion channels: potassium channels. Pharmacol Rev . $55: 583$ - 586

- Guy HR, Seetharamulu P. 1986 ; Molecular model of the action potential sodium channel . Proc Natl Acad Sci USA . 508 : 508 - 512

- Habersetzer-Rochat C, Sampieri F. 1976 ; Structure-function relationships of scorpion neurotoxins . Biochemistry . $15: 2254$ - 2260

- Heinemann SH, Terlau H, Stuhmer W, Imoto K, Numa S . 1992 ; Calcium channel characteristics conferred on the sodium channel by single mutations . Nature . 356 : 441 443

- Hille B . 1968 ; Pharmacological modifications of the sodium channels of frog nerve . J Gen Physiol . 51 : 199 - 219

- Hille B . 1975 ; The receptor site for tetrodotoxin and saxitoxin. A structural hypothesis Biophys J . 15 : 615 - 619

- Hockerman GH , Peterson BZ, Johnson BD , Catterall WA . 1997 ; Molecular determinants of drug binding and action on L-type calcium channels . Annu Rev Pharmacol Toxicol . $37: 361$ - 396

- Hofmann F, Biel M , Flockerzi V . 1994 ; Molecular basis for $\mathrm{Ca}^{2+}$ channel diversity . Annu Rev Neurosci . 17 : 399 - 418

- Huang JMC , Wu CH , Baden DG . 1984 ; Depolarizing action of red tide dinoflagellate brevetoxin on axonal membranes . J Pharmacol Exp Ther . 299 : 615 - 621

- Hwang DF, Tai KP, Chueh CH, Lin LC, Jeng SS . 1991 ; Tetrodotoxin and derivates in several species of the gastropod Naticidae. Toxicon . 29 : 1019 - 1024

- Ishii H, Kinoshita E, Kimura T, Yakehiro M , Yamaoka K, Imoto K, Mori Y, Seyama I . 1999 ; Point-mutations related to the loss of batrachotoxin binding abolish the grayanotoxin effect in $\mathrm{Na}^{+}$channel isoforms . Jpn J Physiol . 49:457 - 61

- Isom LL, De Jongh KS, Patton DE, Reber BFX, Offord J , Charbonneau H, Walsh K, Goldin AL, Catterall WA . 1992 ; Primary structure and functional expression of the $\beta 1$ subunit of the rat brain sodium channel. Science . $256: 839-842$

- Isom LL, Ragsdale DS, De Jongh KS, Westenbroek RE, Reber BFX, Scheuer T, Catterall WA . 1995 ; Structure and function of the $\beta 2$ subunit of brain sodium channels, a transmembrane glycoprotein with a CAM-motif. Cell . 83: $433-442$

- Jaimovich E, Ildefonse M , Barhanin J , Rougier O , Lazdunski M . 1982 ; Centruroides toxin, a selective blocker of surface Na ${ }^{+}$channels in skeletal muscle: voltage-clamp analysis and biochemical characterization of the receptor . Proc Natl Acad Sci USA . $79: 3896$ - 3900

- Jan LY, Jan YN . 1997 ; Cloned potassium channels from eukaryotes and prokaryotes. Annu Rev Neurosci . 20 : 91 - 123

- Jay SD , Ellis SB , McCue AF, Williams ME, Vedvick TS , Harpold MM , Campbell KP . 1990 ; Primary structure of the gamma subunit of the DHP-sensitive calcium channel from skeletal muscle. Science . $248: 490-492$

- Jiang Y, Lee A, Chen J, Cadene M, Chait BT , Mackinnon R . 2002a ; Crystal structure and mechanism of a calcium-gated potassium channel . Nature . 417 : 515 - 522

- Jiang Y, Lee A, Chen J, Cadene M, Chait BT, Mackinnon R. 2002b ; The open pore conformation of potassium channels . Nature . 417 : 523 - 526

- Jiang Y, Lee A, Chen J, Ruta V , Cadene M, Chait BT, Mackinnon R . 2003 ; X-ray structure of a voltage-dependent $\mathrm{K}^{+}$channel . Nature . 423 : 33 - 41

- Jonas P, Vogel W, Arantes EC, Giglio JR . 1986; Toxin gamma of the scorpion Tityus serrulatus modifies both activation and inactivation of sodium permeability of nerve membrane. Pflügers Arch . $407: 92$ - 99

- Jover E, Courauld F, Rochat H . 1980 ; Two types of scorpion neurotoxins characterized by their binding to two separate receptor sites on rat brain synaptosomes . Biochem Biophys Res Commun . 95 : 1607 - 1614

- Kazarinova-Noyes K, Malhotra JD , McEwen DP , Mattei LN , Berglund EO, Ranscht B , Levinson SR , Schachner M , Shrager P , Isom LL , Xiao ZC . 2001 ; Contactin associates with sodium channels and increases their functional expression. J Neurosci . $21: 7517$ - 7525

- Kharrat R , Darbon H, Rochat H , Granier C . 1989 ; Structure-activity relationships of scorpion a-toxins. Multiple residues contribute to the interaction with receptors . Eur J Biochem . $181: 381-390$

- Khera PK, Benzinger GR , Lipkind G, Drum CL, Hanck DA, Blumenthal KM . 1995 ; Multiple cationic residues of anthopleurin B that determine high affinity and channel isoform discrimination. Biochem . $34: 8533-8541$

- Khodorov BI . 1985 ; Batrachotoxin as a tool to study voltage-sensitive sodium channels of excitable membranes . Proc Biophys Mol Biol . 45 : 57 - 118

- Kimura T, Kinoshita E, Yamaoka K, Yuki T, Yakehiro M, Seyama I . 2000 ; On site of action of grayanotoxin in domain 4 segment 6 of rat skeletal muscle sodium channel FEBS Lett . $465: 18-22$

- Kopeyan C, Martinez G, Lissitzky S , Miranda F, Rochat H . 1974 ; Disulfide bonds of toxin II of the scorpion Androctonus australis Hector . Eur J Biochem . 47 : 483 - 489

- Lazdunski M, Frelin C, Barhanin J, Lombet A, Meiri H, Pauron D, Romey G, Schmidt A, Schweitz H, Vigne P, Vijverberg HPM . 1986 ; Polypeptide toxins as tools to study voltage-sensitive $\mathrm{Na}^{+}$channels. Ann New-York Acad Sci . 204 - 219

- Leipold E, Hansel A, Borges A, Heinemann SH . 2006 ; Subtype specificity of scorpion beta-toxin Tz1 interaction with voltage-gated sodium channels is determined by the pore loop of domain 3. Mol Pharmacol . $70: 340-347$

- Leipold E, Hansel A, Olivera BM, Terlau H, Heinemann SH . 2005 ; Molecular interaction of delta-conotoxins with voltage-gated sodium channels . FEBS Lett . 579 : 3881 $-3884$

- Linford NJ , Cantrell AR, Qu Y, Scheuer T, Catterall WA . 1998 ; Interaction of batrachotoxin with the local anesthetic receptor site in transmembrane segment IVS6 of the voltage-gated sodium channel. Proc Natl Acad Sci USA . 95 : 13947 - 13952

- Li-Smerin Y, Swartz KJ . 1999 ; Gating modifier toxins reveal a conserved structural motif in voltage-gated Ca2 ${ }^{+}$and $\mathrm{K}^{+}$channels . Proc Natl Acad Sci USA . 95 : 8585 8589

- Li-Smerin Y , Swartz KJ . 2000 ; Localization and molecular determinants of the Hanatoxin receptors on the voltage-sensing domains of a $\mathrm{K}^{+}$channel . J Gen Physiol . 115 : $673-684$

- Lombet A , Bidard JN , Lazdunski M . 1987 ; Ciguatoxin and brevetoxins share a common receptor site on the neuronal voltage-dependent Na ${ }^{+}$channel . FEBS Lett . 219 : 355 - 359 
- Long SB , Campbell EB , Mackinnon R . 2005 ; Crystal structure of a mammalian voltage-dependent Shaker family potassium channel . Science . 309 : 897 - 903

- Marcotte P, Chen LQ, Kallen RG, Chahine M . 1997 ; Effects of Tityus serrulatus scorpion toxin gamma on voltage-gated Na ${ }^{+}$channels . Circ Res . 80 : 363 - 369

- Malhotra JD , Koopmann MC , Kazen-Gillespie KA , Fettman N , Hortsch M , Isom LL . 2002 ; Structural requirements for interaction of sodium channel beta 1 subunits with ankyrin. J Biol Chem . $277: 26681-26688$

- Martiin-Moutot N, Mansuelle P, Alcaraz G, Dos Santos RG, Cordeiro MN, De Lima ME, Seagar M, Van Renterghem C . 2006 ; Phoneutria nigriventer toxin 1: a novel state-dependent inhibitor of neuronal sodium channels that interacts with mu-conotoxin binding sites . Mol Pharmacol . 69 : 1931 - 1937

- Martin-Eauclaire MF , Couraud F . Editor: Chang LW, Dyer RS . 1992 ; Scorpion neurotoxins: effects and mechanisms . Handk Neurotoxicology . Marcel Dekker ; New York, NY $683-716$

- McCormick KA, Srinivasan J, White K, Scheuer T , Catterall WA . 1999 ; The extracellular domain of the $\beta 1$ subunit is both necessary and sufficient for $\beta 1$-like modulation of sodium channel gating. J Biol Chem . $274: 32638$ - 32646

- McGee AW , Nunziato DA, Maltez JM , Prehoda KE , Pitt GS , Bredt DS . 2004 ; Calcium channel function regulated by the SH3-GK module in beta subunits . Neuron . 42 : $89-99$

- Mebs D , Schmidt K. 1989 ; Occurrence of tetrodotoxin in the frog Atelopus oxyrhynchus . Toxicon . $27: 819$ - 822

- Meves H , Rubly N, Watt DD . 1982 ; Effect of toxins isolated from the venom of the scorpion Centruroides sculpturatus on the Na currents of the node of Ranvier . Pflügers Arch . $393: 56-62$

- Moczydlowski E, Olivera BM , Gray WR, Strichartz GR . 1986 ; Discrimination of muscle and neuronal sodium channel subtypes by binding competition between [ ${ }^{3}$ H] saxitoxin and $\mu$-conotoxins. Proc Natl Acad Sci USA . $83: 5321-5325$

- Morgan K, Stevens EB , Shah B , Cox PJ , Dixon AK, Lee K, Pinnock RD, Hughes J , Richardson PJ , Mizuguchi K , Jackson AP . 2000 ; ß3: An additional auxiliary subunit of the voltage-sensitive sodium channel that modulates channel gating with distinct kinetics . Proc Natl Acad Sci USA . 97 : 2308 - 2313

- Narahashi T . 1974 ; Chemicals as tools in the study of excitable membranes . Plügers Arch . 399 : 813 - 889

- Narahashi T , Moore JW , Scott WR . 1964 ; Tetrodotoxin blockage of sodium conductance increase in lobster giant axons . J Gen Physiol . 47 : 965 - 974

- Nicholson GM , Walsh R, Little MJ , Tyler MI . 1998 ; Characterisation of the effects of robustoxin, the lethal neurotoxin from the Sydney funnel-web spider Atrax robustus , on sodium channel activation and inactivation. Pflugers Arch . 436: $117-126$

- Nicholson GM , Willow M , Howden ME, Narahashi T . 1994 ; Modification of sodium channel gating and kinetics by versutoxin from the Australian funnel-web spider Hadronyche versuta . Pflugers Arch . 428 : 400 - 409

- Noda M, Suzuki H, Numa S, Stuhmer W . 1989 ; A single point mutation confers tetrodotoxin and saxitoxin insensitivity on the sodium channel II . FEBS Lett . 259 : 213 216

- Ohizumi Y, Nakamura H , Kobayashi J , Catterall WA . 1986 ; Geographutoxin II, a peptide sodium channel blocker that selectively inhibits ${ }^{3}$ H] saxitoxin binding to muscle and nerve sodium channels. J Biol Chem . $261: 6149$ - 6152

- Olivera BM , Miljanich GP, Ramachandran J, Adams ME . 1994 ; Calcium channel diversity and neurotransmitter release: The omega-conotoxins and omega-agatoxins . Annu Rev Biochem . $63: 823-867$

- Opatowsky Y, Chen CC, Campbell KP, Hirsch JA . 2004 ; Structural analysis of the voltage-dependent calcium channel beta subunit functional core and its complex with the alpha 1 interaction domain. Neuron . 42:387 - 399

- Papazian DM , Schwarz TL, Tempel BL , Jan YN , Jan LY . 1987 ; Cloning of genomic and complementary DNA from Shaker, a putative potassium channel gene from Drosophila. Science. $237: 749-753$

- Perez-Reyes E . 2003 ; Molecular physiology of low-voltage-activated t-type calcium channels . Physiol Rev . 83 : 117 - 161

- Poli MA, Mende TJ , Baden DG . 1986 ; Brevetoxins, unique activators of voltage-sensitive sodium channels, bind to specific sites in rat brain synaptosones . Mol Pharmacol . $30: 129-135$

- Pongs O, Leicher T, Berger M, Roeper J, Bahring R, Wray D, Giese KP, Silva AJ , Storm JF . 1999 ; Functional and molecular aspects of voltage-gated potassium channel beta subunits . Ann N Y Acad Sci . $868: 344-355$

- Ratcliffe CF, Qu Y, McCormick KA, Tibbs VC, Dixon JE, Scheuer T, Catterall WA . 2000 ; A sodium channel signaling complex: Modulation by associated receptor protein tyrosine phosphatase $\beta$. Nat Neurosci . 3: 437 - 444

- Ratcliffe CF, Westenbroek RE, Curtis R, Catterall WA . 2001 ; Sodium channel $\beta 1$ and $\beta 3$ subunits associate with neurofascin through their extracellular immunoglobulin-like domain . J Cell Biol . $154: 427-434$

- Rodriguez de la Vega RC, Possani L . 2005 ; Overview of scorpion toxins specific for sodium channels: biodiversity, structure-function relationships, and evolution . Toxicon $46: 831-844$

- Rohl CA, Strauss CE, Chivian D, Baker D . 2004 ; Modeling structurally variable regions in homologous proteins with rosetta . Proteins . 55 : 656 - 677

- Rohl CA, Strauss CE , Misura KM , Baker D . 2004 ; Protein structure prediction using Rosetta . Methods Enzymol . 383 : 66 - 93

- Ray R, Morrow CS , Catterall WA . 1978 ; Binding of scorpion toxin to receptor sites associated with voltage-sensitive sodium channels in synaptic nerve ending particles . J Biol Chem . 253: $7307-7313$

- Rettig J , Heinemann SH, Wunder F, Lorra C, Parcej DN, Dolly JO, Pongs O . 1994 ; Inactivation properties of voltage-gated K ${ }^{+}$channels altered by presence of $\beta$-subunit . Nature . 369 : 289 - 294

- Ritchie JM , Rogart RB . 1977 ; The binding of saxitoxin and tetrodotoxin to excitable tissue . Rev Physiol Biochem Pharmacol . 79 : 42 - 50

- Rochat H, Bernard P, Couraud F. 1979 ; Scorpion toxins: chemistry and mode of action . Adv Cytopharmacol . $3: 325$ - 334

- Rogers JC, Qu Y, Tanada TN, Scheuer T, Catterall WA . 1996 ; Molecular determinants of high affinity binding of alpha-scorpion toxin and sea anemone toxin in the S3-S4 extracellular loop in domain IV of the $\mathrm{Na}^{+}$channel alpha subunit . J Biol Chem . $271: 15950$ - 15962

- Ruth P, Röhrkasten A, Biel M, Bosse E, Regulla S, Meyer HE, Flockerzi V , Hofmann F . 1989 ; Primary structure of the beta subunit of the DHP-sensitive calcium channel from skeletal muscle. Science . $245: 1115$ - 1118

- Sanguinetti MC, Curran ME, Zou A, Shen J , Spector PS , Atkinson DL, Keating MT . 1996 ; Coassembly of K ${ }_{\mathrm{V}}$ LQT1 and minK (IsK) proteins to form cardiac $\mathrm{I}_{\mathrm{Ks}}$ potassium channel . Nature . $384: 80-83$

- Sato S , Nakamura H, Ohizumi Y, Kobayashi J , Hirata Y . 1983 ; The amino acid sequences of homologous hydroxyproline-containing myotoxins from the marine snail Conus geographus venom. FEBS Lett . $155: 77-280$

- Schantz EJ . 1986 ; Chemistry and biology of saxitoxin and related toxins . Ann N Y Acad Sci . 479 : 15 - 23

- Schweitz H, Vincent JP, Barhanin J, Frelin C, Linden G, Hugues M, Lazdunski M . 1981 ; Purification and pharmacological properties of eight sea anemone toxins form Anemonia sulcata, Anthopleura xanthogrammica, Stoichactis giganteus, and Actinodendron plumosum. Biochemistry . $20: 5245-52$

- Scott VES , Rettig J , Parcej DN , Keen JN , Findlay JBC , Pongs O , Dolly JO . 1993 ; Primary structure of a $\beta$ subunit of $\alpha$-dendrotoxin-sensitive K ${ }^{+}$channels from bovine brain . Proc Natl Acad Sci USA . 91 : 1637 - 1641

- Sheets MF, Kyle JW , Kallen RG, Hanck DA . 1999 ; The Na channel voltage sensor associated with inactivation is localized to the external charged residues of domain IV, S4 . Biophys J . $77: 747-57$

- Snutch TP, Reiner PB . $1992 ; \mathrm{Ca}^{2+}$ channels: diversity of form and function . Curr Opin Neurobiol . 2 : 247 - 253

- Srinivasan J, Schachner M , Catterall WA . 1998 ; Interaction of voltage-gated sodium channels with the extracellular matrix molecules tenascin-C and tenascin-R . Proc Natl Acad Sci USA . $95: 15753-15757$

- Stefan MM , Potts JF , Agnew WS . 1994 ; The microI skeletal muscle sodium channel: mutation E403Q eliminates sensitivity to tetrodotoxin but not to $\mu$-conotoxins GIIIA and GIIIB . J Membr Biol . $137: 1$ - 8

- Strichartz G, Rando T, Wang GK . 1987 ; An integrated view of the molecular toxinology of sodium channel gating in excitable cells . Ann Rev Neurosci . 10 : 237 - 267 
- Striessnig J . 1999 ; Pharmacology, structure and function of cardiac L-type calcium channels . Cell Physiol Biochem . $9: 242$ - 269

- Swartz KJ , MacKinnon R . 1997 ; Mapping the receptor site for Hantoxin, a gating modifier of voltage-dependent K ${ }^{+}$channels . Neuron . 18 : 675 - 682

- Takahashi M, Seagar MJ , Jones JF, Reber BF, Catterall WA . 1987 ; Subunit structure of dihydropyridine-sensitive calcium channels from skeletal muscle . Proc Natl Acad Sci USA . $84: 5478-5482$

- Takahashi SX , Miriyala J , Colecraft HM . 2004 ; Membrane-associated guanylate kinase-like properties of beta-subunits required for modulation of voltage-dependent calcium channels . Proc Natl Acad Sci USA . 101 : 7193 - 7198

- Takumi T, Ohkubo H, Nakanishi S . 1988 ; Cloning of a membrane protein that induces a slow voltage-gated potassium current . Science . 242 : 1042 - 1045

- Tanabe T, Takeshima H, Mikami A, Flockerzi V, Takahashi H, Kangawa K, Kojima M, Matsuo H, Hirose T , Numa S . 1987 ; Primary structure of the receptor for calcium channel blockers from skeletal muscle . Nature . $328: 313-318$

- Tejedor FJ , Catterall WA . 1988 ; A site covalent attachment of alpha-scorpion toxin derivatives in domain I of the sodium channel alpha subunit . Proc Natl Acad Sci USA . $85: 8742-8746$

- Tempel BL, Papazian DM, Schwarz TL, Jan YN, Jan LY . 1987 ; Sequence of a probable potassium channel component encoded at Shaker locus of Drosophila . Science . $237: 770-775$

- Terlau H, Heinemann SH, Stuhmer W, Pusch M, Conti F, Imoto K, Numa S . 1991 ; Mapping the site of block by tetrodotoxin and saxitoxin of sodium channel II . FEBS Lett . $293: 93-96$

- Thomsen WJ , Catterall WA . 1989 ; Localization of the receptor site for a-scorpion toxins by antibodies mapping: implications for sodium channel topology . Proc Natl Acad Sci USA . 86 : $10161-10165$

- Trainer VL, Baden DG , Catterall WA . 1994 ; Identification of peptide components of the brevetoxin receptor site of rat brain sodium channels . J Biol Chem . 269 : 17114 17119

- Trainer VL, Brown GB , Catterall WA . 1996 ; Site of covalent labeling by a photoreactive batrachotoxin derivative near transmembrane segment IS6 of the sodium channel alpha subunit. J Biol Chem . $271: 11261$ - 11267

- Trainer VL, Thomsen WJ , Catterall WA , Baden DG . 1991 ; Photoaffinity labelling of the brevetoxin receptor site on sodium channels in rat brain synaptosomes . Mol Pharmacol . $40: 988-994$

- Ulbricht W. 1969 ; The effect of veratridine on excitable membranes of nerve and muscle . Ergeb Physiol . $61: 18$ - 71

- Van Petegem F, Clark KA, Chatelain FC, Minor DL Jr . 2004 ; Structure of a complex between a voltage-gated calcium channel beta-subunit and an alpha-subunit domain . Nature . $429: 671-675$

- Vijverberg HP, Pauron D , Lazdunski M . 1984 ; The effect of Tityus serrulatus scorpion toxin gamma on Na channels in neuroblastoma cells . Pflügers Arch . 401 : 297 - 303

- Wang GK , Strichartz GR . 1983 ; Purification and physiological characterization of neurotoxins from venoms of the scorpions Centruroides sculpturatus and Leiurus quinquestriatus . Mol Pharmacol . $23: 519$ - 33

- Wang SY, Wang GK . 1999 ; Batrachotoxin-resistant $\mathrm{Na}^{+}$channels derived from point mutations in transmembrane segment D4-S6 . Biophys J . 76 : 3141 - 3149

- Wang SY, Wang GK . 1998 ; Local anesthetic block of batrachotoxin-resistant muscle $\mathrm{Na}^{+}$channels . Mol Pharmacol . 54 : 389 - 96

- Winterfield JR , Swartz KJ . 2000 ; A hot spot for the interaction of gating modifier toxins with voltage-dependent ion channels . J Gen Physiol . 116 : 637 - 644

- Yamasuto T, Nagal H, Yasumura D, Michishita T, Endo A, Yotsu M, Kotaki Y . 1986 ; Interspecies distribution and possible origin of tetrodotoxin . Ann NY Acad Sci . $479: 44-51$

- Yanagawa Y, Abe T , Satake M . 1986 ; Blockade of $\left[{ }^{3}\right.$ H]lysine-tetrodotoxin binding to sodium channel proteins by conotoxin GIII . Neurosci Lett . 64 : 7 - 12

- Yarov-Yarovoy V, Schonbrun J , Baker D . 2006a ; Multipass membrane protein structure prediction using Rosetta . Proteins . 62 : 1010 - 1025

- Yarov-Yarovoy V , Baker D, Catterall WA . 2006 ; Voltage sensor conformations in the open and closed states in ROSETTA structural models of K ${ }^{+}$channels . Proc Natl Acad USA . $103: 7292$ - 7297

- Yu FH , Catterall WA . 2004 ; The VGL-chanome: a protein superfamily specialized for electrical signaling and ionic homeostasis . Sci STKE . re15 -

- Yu FH, Westenbroek RE, Silos-Santiago I, Scheuer T, Catterall WA, Curtis R . 2003 ; Sodium channel $\beta 4$ : A disulfide-linked auxiliary subunit structurally and functionally similar to $\beta 2$. J Neurosci . $23: 7577-7585$

- Zhang M , Jiang M , Tseng GN . 2001 ; minK-related peptide 1 associates with Kv4.2 and modulates its gating function: potential role as beta subunit of cardiac transient outward channel? . Circ Res . $88: 1012$ - 1019

- Zhao Y, Yarov-Yarovoy V, Scheuer T, Catterall WA . 2004 ; A gating hinge in sodium channels: a molecular switch for electrical signaling . Neuron . 41 : 859 - 865

- Zhou M , Morais-Cabral JH, Mann S , Mackinnon R . 2001 ; Potassium channel receptor site for the inactivation gate and quaternary amine inhibitors . Nature . 411 : 657 661 


\section{Figure 1}

The voltage-gated ion channels

A. The different members of the ion channel protein family structurally related to the voltage-gated ion channels are illustrated as transmembrane folding diagrams in which cylinders represent probable transmembrane alpha helices. Red, S5-S6 pore-forming segments; green, S4 voltage sensor; and blue, S1-S3 transmembrane segments. B. Auxiliary subunits of the voltage-gated ion channels. The auxiliary subunits of $\mathrm{Na}_{\mathrm{V}}, \mathrm{Ca}_{\mathrm{V}}$, and $\mathrm{K}_{\mathrm{V}}$ channels are illustrated, with cylinders representing predicted alpha helices of the transmembrane subunits. $\mathrm{N}$-linked carbohydrate chains are indicated by $\Psi$. The intracellular auxiliary subunits are illustrated by their predicted three-dimensional structures.

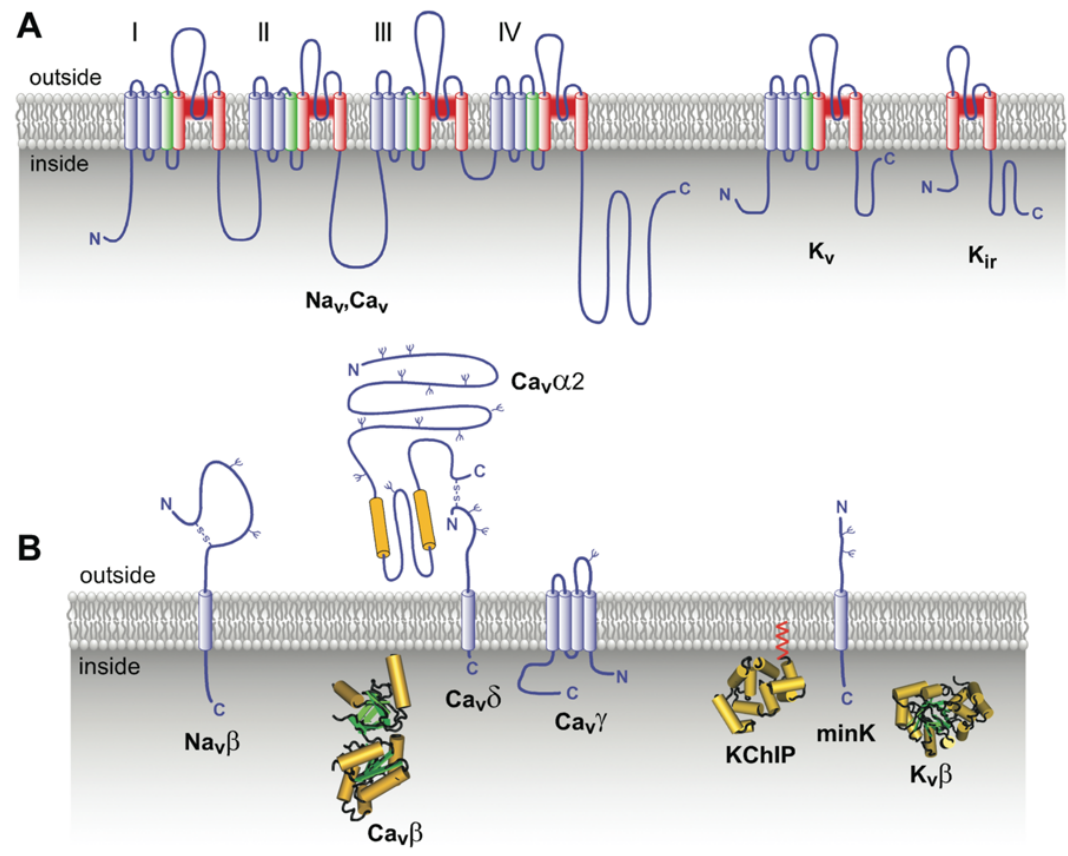

\section{Figure 2}

Neurotoxin receptor sites on voltage-gated sodium channels

Locations of the neurotoxin receptor sites on mammalian sodium channels are illustrated by colors, as indicated in the Figure.

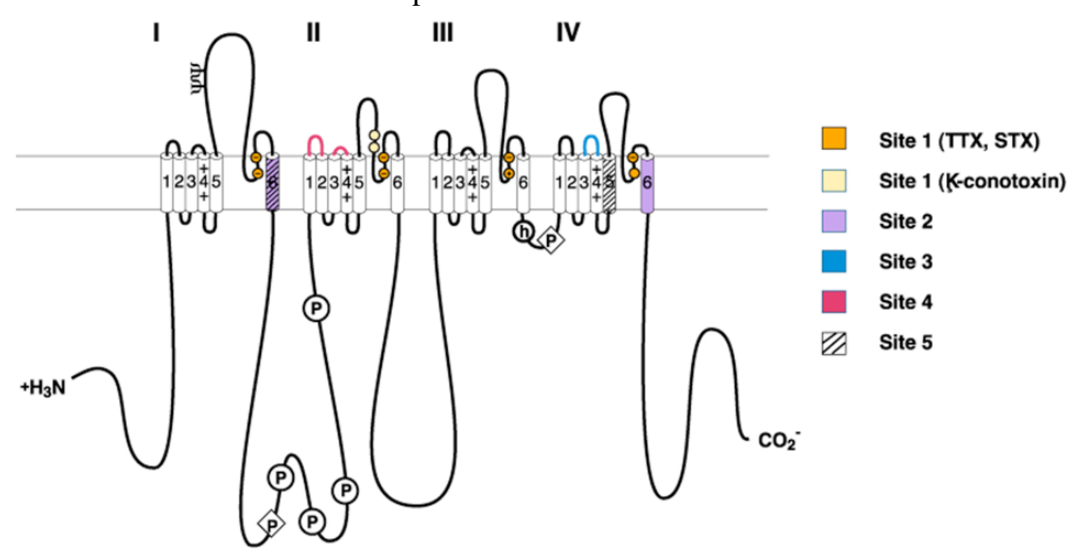




\section{Figure 3}

Structures of potassium channels

A. Open and closed conformations of the potassium channel pore structures. Two subunits of the bacterial $\mathrm{K}^{+}$channels of KcsA (Doyle et al., 1998 ), representing a "closed" conformation, and MthK (Jiang et al., 2002b ), representing an "open" conformation, are shown in the figure. The selectivity filter is yellow, and the outer helix (analogous to S5) is depicted adjacent to the lipid bilayer. The inner helix (analogous to S6) is marked with a space-filling model of the conserved glycine residue (red), which is thought to be critical for the bending of the S6 helix in the open conformation (Zhao et al., 2004 ). B. Cross-section through the three-dimensional structure of a tetrameric $\mathrm{K}_{\mathrm{V}} 1.2$ channel (Long et al., 2005a,b ). Center, the pore regions S5-P-S6 of two subunits, designated 1 and 3, in blue-green. Left, S1 through S4 of subunit 4, whose S5-P-S6 segments project in front of the plane of the figure and form the near side of the pore. Right, S1 through S4 segments of subunit 2 , whose S5-P-S6 segments project behind the plane of the figure and form the far side of the pore. As illustrated, the voltage-sensing domain composed of the S1 to S4 segments is positioned to interact with the S5-P-S6 segments of the adjacent subunit located clockwise (as seen from the extracellular side) in the symmetrical tetrameric array.

A

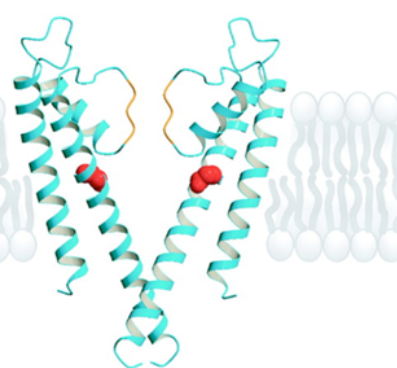

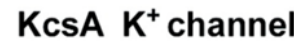 "closed"}

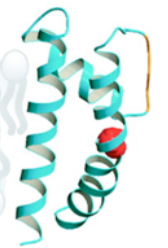

MthK $\mathrm{K}^{+}$channel "open"

B

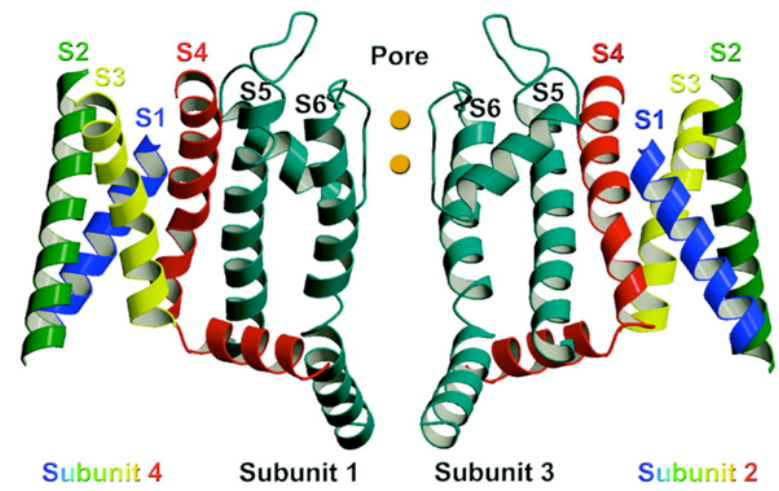




\section{Figure 4}

Structural model of $\beta$-scorpion toxin binding to $\mathrm{Na}_{\mathrm{v}} 1.2$

Docking model of the $\beta$-scorpion CssIV toxin binding to the voltage-sensing segments of domain II of $\mathrm{Na}_{\mathrm{v}} 1.2$, generated as described in the text and in Cestèle et al. (2006) . A molecular surface representation of the toxin-receptor complex is illustrated. To demonstrate overall shape complementation, the model for the $\beta$-scorpion toxin CssIV was separated from the sodium channel model. Side chains of selected residues are labeled with corresponding residue numbers. Side chains are colored as white for hydrophobic residues, blue for positively charged residues, red for negatively charged residues, and green for polar but uncharged residues.

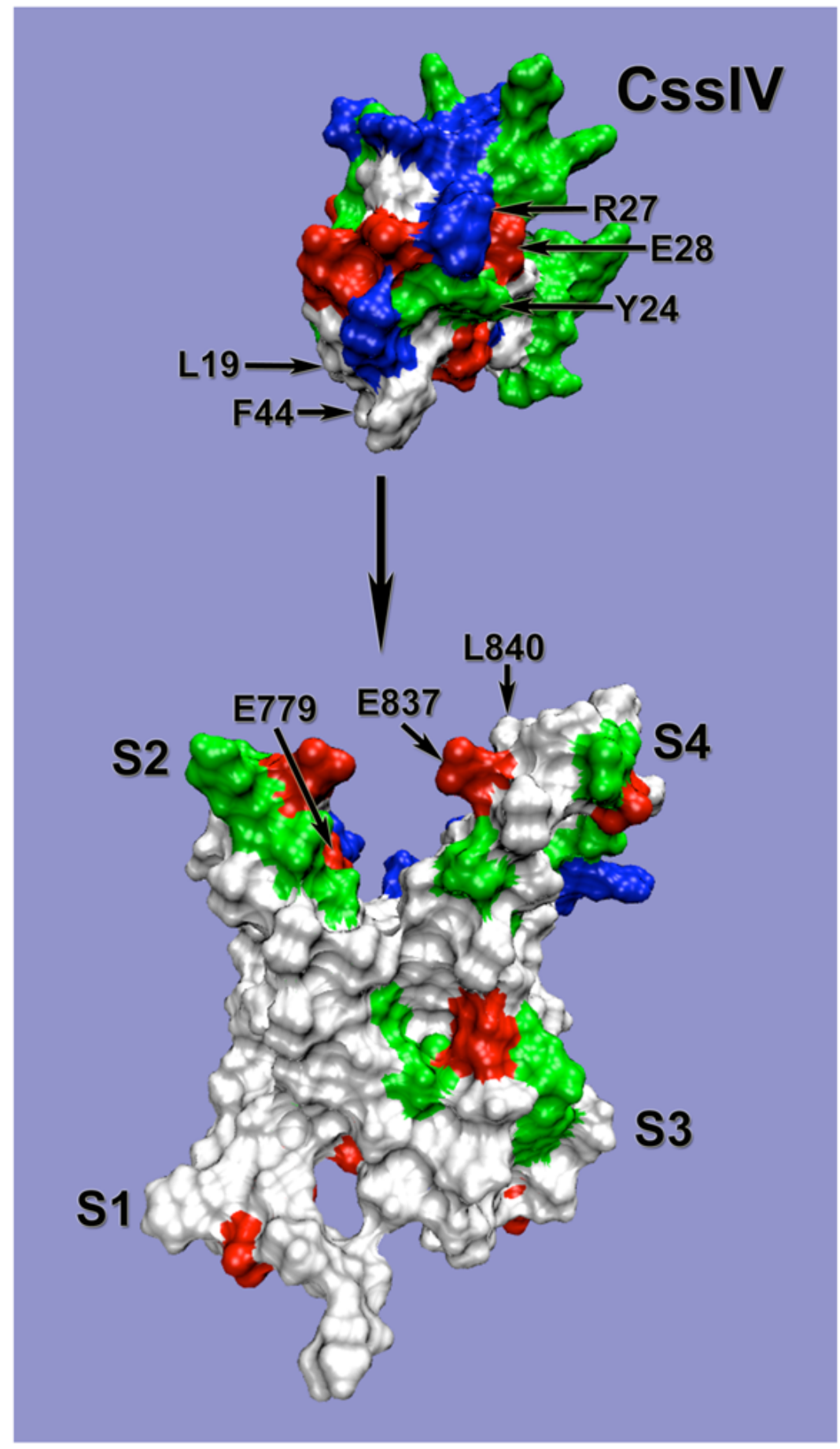

\section{Scheme 1}

$\mathrm{Na}_{\mathrm{v}} 1.2$ Domain II $\mathrm{Na}_{\mathrm{v}} 1.2$ Domain IV

$\mathrm{K}_{\mathrm{v}} 2.1$

VVILSIVGMFLAELIEKYFV---SPT S4

$\mathrm{Ca}_{\mathrm{v}} 2.1$ Domain IV

S3 AILPYYVTIFLTESNKSVLQFQNVRR

S3 TVLGSITDILVTEFGNNFIN----LS S4 
Table 1

Neurotoxin Receptor Sites on Voltage-gated Sodium Channels

Receptor Site

Functional Effect

Tetrodotoxin

Pore block

Site 2

$\mu$-Conotoxin

Batrachotoxin

Veratridine

Persistent activation, enhanced activation, \& block of inactivation

Grayanotoxin

Site 3

Aconitine

a-Scorpion toxins Slowed inactivation

Sea anemone toxins

Atrachotoxins

Site 4

Site 5

$\beta$-Scorpion toxins

Brevetoxins

Ciguatoxin

Site 6

ס-Conotoxins

Enhanced activation

Enhanced activation \& block of inactivation

Slowed inactivation 